\title{
A Cognitive Study of News Reports of China Daily and Washington Post on Diaoyu Island Issues
}

\author{
Na Wang \\ English department, Yanshan University \\ Qinhuangdao City, China \\ Email:wangna@ysu.edu.cn
}

\author{
Wenrui Lian \\ English department, Yanshan University \\ Qinhuangdao City, China
}

\begin{abstract}
Diaoyu islands issue has become the hot topic since 2012. China Daily and Washington Post are chosen as research subject, who are representative news agencies with great authority of two countries representing their countries' and people's attitude. The author chose 8 news reports respectively from the two news agencies over Diaoyu island issue, combining political news and conceptual metaphor, finding out the similarities and differences in the use of conceptual metaphor of these two news agencies based on mapping mechanism, and revealing their attitude and political stance over the Diaoyu islands issue. It has been found that there are some metaphors commonly used by two news agencies, while some metaphors are preferred. Besides, China holds unshakable political stance in protecting its own territory rights. America's attitude over the island dispute between China and Japan is constantly changing.
\end{abstract}

Key words-conceptual metaphor; China Daily; Washington Post; Diaoyu island issue

\section{INTRODUCTION}

In daily life, generally metaphor is believed by common people to be a kind of rhetorical device, consisting of wide imagination and beautiful words. "The other side is that once a conceptual metaphor becomes established, it will impose its structure on real life through creating new correspondences in experience and will be realized." (Lan, 2003:39) In Metaphors We Live By George Lakoff and Mark Johnson argue that metaphors are pervasive in everyday life, not just in language, but also in thought and action (1980). "Metaphor is a conceptual matter, often unconscious, and that conceptual metaphors underline everyday language as well as poetic language" (Lakoff \&Turner, 1989: 136) They explain how to understand and experience one kind of thing in terms of another, which is the metaphor using process.

Structurally speaking, a conceptual metaphor consists of the target domain and the source domain. It is to use expressions from one domain to talk about corresponding concepts in the metaphorically defined domain (Lakoff \& Johnson, 1980:52). The essence of conceptual metaphor is the projection and conceptual combination that uncommon and abstract concepts in target domain are mapped onto common and familiar concepts in source domain. (Liu \& Wang, 2012). Selectivity is the substantial character of the metaphor mapping. (Liu, 2003) The mapping is not arbitrary, which follows the Invariance Principle (Lakoff \& Turner, 1989):"metaphorical mappings preserve the cognitive topology of the source domain, in a way consistent with the inherent structure of the target domain".

This paper applies conceptual metaphor theory to compare 8 pieces of news reports respectively from China Daily and Washington Post. Those two news agencies represent the different voices towards the international political events, cultural conflicts and economic activities from the two countries, China and USA. They are two of the most popular international news agencies, which convey the information to people and lead or at least influence people's opinion on things. Also, it demonstrates the two countries' different foreign policy, political attitude, and cultural elements. All the news reports from China Daily and Washington Post that concerned in this thesis are found

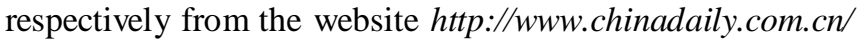
and http://www.washingtonpost.com/.

\section{WAR METAPHOR}

War metaphor is most commonly used in political discourse both from American data and Chinese data. Metaphors from this source domain "war" usually include such words as "conflict", "confrontation", "challenge"," threaten"," strategy", " defend"," interests" and "take one's side".

\section{A. War Metaphor in American Data}

1. The State Department says it has no position and leaves it to China and Japan to decide, but also that, in the event of a military conflict over the island, America's treaty with Japan would require it to take that country's side

2. Chinese ships have been pushing near the islands more aggressively, so Japan may be seeking louder American support as a deterrent.

3. Washington, anxious to avoid a confrontation with China so early in the tenure of $\mathrm{Xi}$ Jinping, the ruling Communist party's new leader, has told Japan not to give China an excuse to overreact.

Regarding China and Japan's contest for islands territory in East China Sea as two parties in a war, they are enemies against each other. Both of them want to own the island territorial sovereignty, which is mapped to the CAUSE OF WAR. During the contest, they like to look for AN ALLY to improve their military strength over an opponent's. From the sentences 2 , it can be told that America decides to take 
neutral attitude towards the island dispute between China and Japan, while it still obeys the treaty signed before with Japan to be with Japan's side. From the sentence 3, it becomes more clear that America is Japan's ally, even thought it gives an absurd analysis on current situation ignoring the justice and historical fact. The dispute between the two parties leads to the anger from two sides in the sentence. CONFROTATION is a must phenomenon in a war, in which participants are enemies against each other. Here Washington, who has realized the China's strong decision to defend island territory in East China Sea, avoids the confrontation with China, showing that it does not want be an opponent against China and has changed its attitude towards the dispute between China and Japan. The reason behind it is that China has big influence on Unite State's development in economic, political and other areas.

4. Although Tokyo and Beijing have been long at odds over the rocky chain of remote islands----the countries have competing narratives about decades- and centuries-old claims----tension spiked in September when Japan bought three of the islands from a private owner.

5. As China and Japan continue to wrangle over a chain of uninhabited islands that have sparked protests in countries, near-miss naval incidents, and lots of tough words, diplomats from both Asian powers are increasingly emphasizing the United States' role in the dispute.

ARGUMENT IS WAR. Here two countries have discussed it for a long time and hold different opinions on the island issue, so they are AT ODD and WRANGLING OVER it. Both of them make efforts to find the evidence for proving their acclamation. TENSION can be spiked and escalated in a war. Japan's buying three of the islands from a private landowner is the cause of this tension. In this argument, one party's inappropriate behavior or words may ignite the anger of the counterpart. Therefore tension is spiked in this argument.

\section{B. War Metaphor in Chinese Data}

6. Observers warned that Tokyo must take the blame for souring Sino-Japanese ties because it has repeatedly gone back on its word and betrayed an agreement it made with Beijing decades ago about shelving the dispute.

7. Historical evidence, including World Two documents, proves that China's claim is irrefutable.

When any participants in a war can not be the winner in short period and the disputes can not be solved, to shelve the dispute is one of ways to stop the fights and develop their relations, which is beneficial for any of them. Because of historical reasons, this islands issue was put aside, but now Japan goes against the agreement China and Japan once reached.

8. "Some neighbors have challenged China's maritime rights and interests because of their own strategic and national interests," "Li said.

9. China should firmly guard its lawful rights and interests when threatened, and its diplomacy "should be flexible enough to stop situations spiraling out of control", Qu said.

CHALLENGE, THREATEN, GUARD and OUT OF CONTROL are often seen in war. Due to participants' different interest one of the two parties will choose to spark the war, and the other will defend itself and fight against its enemy for its own interests. To keep everything under control is the key to win. If China's attitude is obvious that country's interests are threatened, China will defend itself and take proper strategy to control the situation.

10. The office, which will have 15 employees, will coordinate within the government and draw up publicity strategies on territorial issues, according to Japanese media.

11. Liang Yunxiang, a professor of Japanese studies at Peking University, said the new office will affect SinoJapanese ties and further provoke China.

In war because of equal military strength, both of parties may reach an impasse or tension between them reaches a white-hot. Then it becomes necessary for one party to break the standoff. Here Japan establishes an office to produce STRATEGY for winning in this island dispute, which PROVOKES China.

\section{FAMILY METAPHOR}

The metaphor of "A country is a family" is used in both Chinese and American data. In this metaphor, many aspects of a family are mapped onto the concept of a country for helping convert an abstract concept, a country, to a detailed concept, a family for better understanding. Within the "family" metaphor, a nation is conceptualized as a family with a capital of a country as a leader, people as children, neighboring countries as family neighbors and so on.

\section{A. Family Metaphor in American Data}

12. Although Tokyo and Beijing have been long at odds over the rocky chain of remote islands----the countries have competing narratives about decades- and centuries-old claims----tension spiked in September when Japan bought three of the islands from a private landowner.

Here the principle of least efforts, one of cognitive principles, is made good use to substitute or represent its country and people. Tokyo and Beijing, the capital of Japan and China respectively, can represent its government or senior officials or its people to express their ideas or policies. In a family, there must be a leader, who is the spokesman or the authority to make family decisions. Tokyo and Beijing, as the capital of whole country individually, play a very leading role in their countries.

13. The other irony gets to the Obama administration's effort to open a "Pacific century" of American leadership in Asia.

14. If the United States wants to maintain the sort of leadership position in the Pacific that both China and Japan seem to believe it currently holds, then Asia's powers may continue looking to it on regional disputes such as this one. 
In a family, there must be a leader to represent his family members and express their opinions or make a decision. Here AMERICAN LEADERSHIP in Pacific Region can be inferred that U.S. wants to play the role of parents, lead and represent Asian countries. In turn, it wants the Asian countries to follow its steps, LOOK TO it and respect it as a parent or big brother, and handle over the disputes among them to it, their leader, for helping deal with them fairly. It is obvious that American foreign policy strategy in Pacific Region is aiming to lead, control, and govern Asian countries and to be a biggest winner.

\section{B. Family Metaphor in Chinese Data}

15. Beijing has lodged solemn representations to Tokyo and said "nobody is ever allowed to trade in China's sacred territory".

16. The official said the islands "have been under the administrative control of the government of Japan since they were returned (by the US) as part of the reversion of Okinawa in 1972". Beijing on Tuesday expressed "grave concern and strong opposition" to the related remarks.

17. The timing of the drill, and Washington's involvement, will complicate the situation, analysts said.

18. After announcing its shift of strategic emphasis back to the Asia-Pacific region, Washington is using the Diaoyu Islands issue as a chance to speed up its military revamp in the region, observers said.

Here the principle of least efforts, one of cognitive principles, is made good use to substitute or represent its country and people, which is the same as the family metaphor use in American data. Both news agencies regard the capital of a country as a leader or a parent of family, who has the authority to make a decision representing its family members, which is same to the capital who makes a decision representing its country people.

19. Wang Fan, director to the Institute of International Relations at the China Foreign Affairs University, said the drills “will only escalate Tokyo's tensions with its neighbors, instead of helping resolve them".

Different families live close to each other in the same community. Then they can call each other as neighbors. Here surrounding COUNTRIES are called as NEIGHBORS. It is important to keep good relationship with neighbors for one's own development. The tension escalated by Tokyo does harm to Asian countries without any good effect.

Besides WAR and FAMILY metaphors, in both American data and Chinese data there are JOURNEY and HUMAN metaphors which, because of the limitation of words, are not talked about in detail.

\section{UNIQUE CONCEPTUAL METAPHOR}

Not all the metaphors are shared by both Chinese data and American data. The author finds out that the cuisine metaphor is only used in American data, while the court metaphor is only used in Chinese data.

\section{A. Cuisine Metaphor}

20. Tension simmering between U.S., China over uninhabited islands' ownership.

21. Defense Secretary Leon E. Panetta arrived in Tokyo on Sunday for a week-long visit to the region and said he would urge Chinese and Japanese leaders to tone down a brewing political crisis over uninhabited islands in the East China Sea.

Simmer and brew are the words often used in cuisine process, but here they are used to describe the prelude of islands dispute between China and Japan. In cuisine, when you simmer food or when it simmers, you cook it by keeping it at boiling point or just below boiling point. Hereby in political discourse, the use of it means that the tension between China and Japan is escalated, which almost leads to the military conflict, the boiling point. Brew is a verb used to the process of making drinks of tea, coffee or beer. Here $a$ brewing political crisis means that the political crisis is undergoing or is in preparation. It indicates that the relationship between China and Japan is in tension, and there is a possibility of the happening of military conflict based on that both countries do not want to concede in this island territorial dispute.

\section{B. Court Metaphor}

\section{Beijing accuses Tokyo of lying about targeting}

23. Japan is defaming the Chinese military by spreading groundless allegations about the so-called radar targeting bye China of a Japanese gunboat, China's military spokesman said on Thursday.

24. Jiang Xinfeng, an expert on Japanese studies at the PLA Academy of Military Sciences, said Tokyo is trying to make China a scapegoat and "prompter of emergencies" through media hype on the radar allegation, and it wants Beijing to be blamed.

ACCUSE, DEFAME, ALLEGATION, SCAPEGOAT, are the words often used in the court. Here Japan is an accuser and China is a defender. Japan makes fabrication that China uses so-called radar to target at a Japanese gunboat, accusing China of wrongdoings. It spreads false information to make China suffer its crime. China responds it strongly, refutes the accusation and points out that Japan takes advantage of media hype to mislead international public opinion. Even though they are not facing each other in the court and offering the evidence for proving counterpart's crime, they are making use of court metaphors to reach their goals.

The use of court metaphor tells that China get used to making good use of legal means to convince others through reasoning and gain the international support providing historical facts and Japan's illegal behaviors.

\section{CONCLUSION}

The paper has made a comparative study of conceptual metaphors applied in news reports from China Daily and Washington Post over Diaoyu islands issue in East China Sea for finding out the differences and similarities in conceptual 
metaphor in both news agencies and revealing two countries' attitude or policy towards this issue.

Firstly, the use of metaphor is very popular in the political news discourses especially the use of war metaphor. China Daily and Washington Post, two representative news agencies of two countries, share some common conceptual metaphors use, including war metaphor, family metaphor, human metaphor, and journey metaphor. War metaphor is most common used in political news reports, which takes a large part of political news reports, especially dealing the political disputes with foreign countries.

Secondly, court metaphor is unique in Chinese data, from which it can be told that China likes to make good use of international law and historical fact to resolve the dispute and gain the international support. It also indicates that China is doing its best to avoid military fight against Japan but to resolve it through negotiation and dialogue, which is influenced by traditional Chinese culture. However, it does not mean that China will concede in this territorial dispute.

Thirdly, through the family metaphor use in Chinese data, it can be seen that China's foreign policy is deeply influenced by Chinese traditional culture that a neighbor is very important to a family and keeping a good relationship with a neighbor is helpful for a family's development.

Fourthly, it can be seen that American attitude towards the dispute between China and Japan is changing. At the beginning, America is very proud of itself, believing that China and Japan look on to it for resolving this dispute. And it has said that it is the hope from both China and Japan that let U.S. take part in this dispute, which sounds absurd. According to its public expression, it can be told that U.S. is on Japan's side. Washington expresses that it will keep neutral in this dispute, but it "falls within Article 5 of the USJapan Security Treaty", US State Department spokeswoman Victoria Nuland said on Thursday. American attitude is contradictory in both sayings. China's firm stance and attitude over the islands territorial issue is out of American expectation. After realization of complication of islands dispute, America finds it hard to handle this issue, decides to remain neutral and tells Japan that "we've make very clear our desire to see cooler heads prevail."

Fifthly, China prefers to make use of the journey metaphor for expressing the social development, such as "path of peaceful development". Actually, China prefer to use PATH for indicating the development or process in economy, society, civilization and other aspects, which is a kind of Chinese language habit.

The last point is that conceptual metaphor is more widely used in American data than those in Chinese data, which shows that there exists a language gap in using conceptual metaphor in English.

\section{REFERENCES}

[1] Aristotle. 1954. Rhetoric and Poetics. New York: The Modern Library.

[2] Fairclough, N.1992. Language Awareness. London: Longman Group UK Limited.

[3] Hunston, S., \& Thompson, G. 2000. Evaluation: An introduction. Oxford: Oxford University Press.

[4] Lakoff. G. 2004. Don't Think of an Elephant. Canada: Chelsea Green Publishing Company.

[5] Lakoff, G. \& M. Johnson. 1980. Metaphors We Live by. Chicago: The University of Chicago University Press.

[6] Lakoff, G, \& Turner, M. 1989. More Than Cool Reason. Chicago: University of Chicago Press.

[7] Lakoff,G. 1993. The Contemporary Theory of Metaphor. In Ortony, Andrew (Ed.).Metaphor and Thought (2nd edition). Cambridge: Cambridge University.

[8] Lan C, 2005, Cognitive Linguistics and Metaphor Study. Beijing: Foreign Language Teaching and Research Press.

[9] Leezencerg, M. 2001.Context of Metaphor. Oxford: Elsevier Science.

[10] Liu H. 2007. The application of systematic functional grammar ---the example of analysis of news discourse. Exam Weekly, NO. 29. pp. $59 \sim 60$.

[11] Liu Z.2003. Essential feature of cross-mapping of metaphor. Foreign Journal, 114(3). pp. 8-14.

[12] Wang J \& Z Yang. 2012. On the feasibility application of metaphor use in political news discourse. Journal of Northeast Normal University; Philosophy and Social Sciences, NO.3, p111 